\title{
The Empowerment of Traditional Market Collaboration towards the Economic Independence of Small Traders in Indonesia
}

\author{
Dr Mappamiring P., M.Si. \\ Lecturer at the High School Of Economics \\ Makassar (Stiem Bongaya). Makassar City, \\ South Sulawesi, Indonesia
}

\begin{abstract}
This type of research is qualitative through the phenomenology of approach, but the results showed that the existence of traditional markets get hold of very important in underpinning the development of the economy, the presence of traditional markets is a container place distributing agricultural goods and will make the economy can run both macro-scale or the scale of microeconomic activities in the traditional market imposes upon the implementation of the economic activities that have an impact on development in many other fields, for that Government needs to build the economy of the traditional market traders by involving the various aspects and all stake holder, private as well as academicians in order to keep together to keep traditional markets still exist in the middle of a fast-paced development progress, sophisticated and modern.
\end{abstract}

Keywords:- Empowerment, Development, markets, collaboration, merchant, independence.

\section{INTRODUCTION}

The presence of traditional markets in the middle of metropolitan city often seen as trivializing a spot buying and selling goods, Staples, this is because the Setup is not neat, tend to take on the road and an irregular arrangement, so impressed slums and less interesting, but nonetheless many societies varying among happy visiting traditional markets, it caused market conditions is extremely complex with a number of characters sellers are varied, in a sense it is sometimes generally regional language as contributing to local language in order to attract buyers one another tribes, on the other hand, the fate of the traditional markets that became the main distribution channel people's agricultural Indonesia, currently located at the tip of the Horn because it is not able to compete with modern markets. Though not a few communities that drape her life to the traditional market. When the crisis hit the economy, traditional markets were able to become a Sustainer of life most of society Indonesia, both self-described as merchants, or farmers are only able to market the results were being passed the people's market. With the more traditional market knocked out imposes on local suppliers who generally can't get into major retailers.
The growth of modern markets proved harm traditional market positioning and other traditional retail-retail in the vicinity. As a result of Government policies that allow the construction of many modern market, according to Market Traders Association Throughout Indonesia (APPSI), since the year 2004, eight markets in Jakarta closed because abandoned purchasers and overhead cost is quite high, i.e. Blora market, Cipinang Baru, Cilincing, Kramat Jaya, Muncang,-carving Business Center, North Beam and rubber Pedurenan. Merchants who are unemployed is estimated to be at least reach 2,100 traders. Traders who survived until the current decline in turnover of up to 75 percent. While other traditional markets in the region Jakarta, occupancy rates of only 40-60\% as well as abandoned purchasers. Note the APPSI mention, of the total 151 traditional markets in Jakarta, there were 51 market adjacent to the modern market and adjacent to hypermarkets there are 45 market, with the average radius of the proximity of less than $2.5 \mathrm{~km}$. E.g. market Mede Pondok Pinang Market, and Pondok Indah adjacent to the Carrefour Lebak Bulus and Giant. In Cempaka Mas, adjacent to the Carrefour Cempaka Putih Market, Gembrong Market and the market of stone Wells. In Depok, within a radius of five kilometers from Depok there are three traditional markets (Pecan Market advance, Market Singapore Jaya and the old market) and around it anyway in the wake of 5 modern market (Margocity, Depok Town Square, Plaza Mall Depok, Depok, Depok and ITC). to date the year 2018 market traditional activities still occupy strategic positions and became the attraction for residents as well as tourists to visit traditional markets, can be exemplified in Makassar there are number of hundreds of markets that operate good permanent nature such as market karuwisi market panampu market, eggplant, marcaya market, pabaeng-baeng market, butung market eggplant, can be estimated there were thousands of people who visit the to where it's not just the population of traders from Makassar city various regions and visitors from outside Makassar come and go, of the phenomenon is already a tangible evidence that economic power one of which is located on the small business sector, traders in traditional markets, besides that there is a market which is not the impromptu nature or permanent move depending on the situation and conditions. 


\section{$>$ Formulation Of The Problem}

How the Government's efforts towards the reinforcement of economic traders at traditional markets in South Sulawesi?

\section{A REVIEW OF THE LITERATURE}

\section{A. Market}

Market as a form of public service site of buying and selling goods to the community, is one reflection of the economy and the social culture of each community in this world. Along with the times, from time to time the market experienced the evolution of place and how to manage them, from traditional to modern to become acidic. The development of shopping venues in the cities in the world, both in Western countries as well as Asia, all of them through the stages, ranging from the traditional market, which then undergoes a process of modernization into a department store (Department store), a chain of stores, shopping centers, department stores, supermarkets. This modernization process is inseparable from changes in demographic patterns, specialization and diversification of the profession, as well as the structure of social, economic and cultural changes in society (West, 1994).

The presence of traditional markets in the modern era as it is today is not only needed, but also can not be separated from the life of the Community system of Indonesia. This condition is caused due to most of Indonesia society there are still many who have not understood the benefits of science and technology advances, such as shopping over the internet. Until now according to Basalah traditional market is still the dominant role in Indonesia and still sorely needed its existence, especially for a middle-class society down. According to Geertz in traditional market pressure in the competition is not between the persistence of sellers with other sellers, but rivalry between the persistence of sellers with potential buyers in the process of bargaining (Narwoko \& Bagong, 2004:281) man is a sentient homo economics that is always looking to gain the maximum benefit with the sacrifice of the smallest detail. Therefore when buying items will always choose the largest benefits with a certain price or the price is cheapest.

Sellers who want to obtain high prices, the item will not be sold, because it directly rivaled until forced to lower the price. The needs and desires of the buyer that varies is the guidelines for traders in carrying out its business. The buyer usually shows the preferences and priorities of different goods. They generally want products and services that satisfy their needs at compete. Differences is what creates the market segment for the buyer. The behavior of buyers is the actions of individuals who are directly involved in the business of acquiring, using, and determine which products and services, including in the decision-making process that preceded and followed the actions (Setiadi, 2003:93).

In General any buyer wants the goods of high quality at low prices and convenient shopping atmosphere, clean and available amenities needed buyers such as electronic transaction (ATM and card credit) and the availability of a vast parking lot. All of these facilities surely there are on the market. Satisfying buyers is the key to success in conducting the business of the trade. Various responses from customers to be accepted as a useful input to development of a trade, therefore merchants in achieving its objectives the need to know what is wanted and required by the purchasers. But it is not easy for merchants to get to know the character and behavior of purchasers, because what could be disclosed it is contrary to fact.

Market activity is one of the intermediaries in the delivery of goods and services to consumers or in other words, the market is the container for all the economic activities of the community. The market will run well in the distribution of goods and services going well anyway, delay distribute result against disrupted the provision of goods and services in the market, which may then result in obstacles to human activities meet his needs. In the business of production, the position of producers and consumers are equally important, one party produces while others need it. To deliver goods and services to the consumer much in the way that is done, one of which is through the market. The community comes to market buy a wide variety of needs, transaction, and resulted in a turnover. Therefore, the market became the driving force of the people's economy. The market also has another role as follows: the role of the market to producers. The important role of the market for producers include: as a place to introduce goods/promotion, as a venue for selling their production. As a place to acquire production/production factors. The role of the market to consumers. For consumers, the market plays an important role because it makes it easy for them to get the needed goods. The more types of goods available on the market so that more and more consumers will come because consumers will be more easy to find the items needed. The role of the market for human resources. The existence of markets can open up opportunities for the community in obtaining work and be an entrepreneur. The bustling market visited the consumer will be able to grow and able to absorb large amounts of labor so that it is capable of help in suppressing unemployment figures. The role of the Market for development.

The growing market will bring a positive impact to the lives of the people. The community will be more prosperous. The need for development also obtained on the market. In addition the country earns income from the activities of the market through tax and levy. The reception can be used as one source of National or regional development.

\section{B. Public Policy Theory}

Public policy is one of the rules made by the Government and is part of a political decision to tackle various problems and issues that exist and flourish in the community. It is also the public policy decisions made by the Government to perform a particular action choice not to do something or to do a certain action. 
Public policy is what is selected by the Government to be done or not done. Carl Friedrich in Dede Mariana (2010) sets forth that the policy is potentially experiencing unplanned actions or activities proposed by a person, group, or Government in an environment where there are particular barriers ( the difficulties) and the possibilities (opportunities) where the policy is proposed in order to be useful in addressing it to achieve the objectives in question.

Public policy is needed, at least because: 1) public policy is regulation; 2) Regulation is a rule created the State organizers namely Government; 3) So, public policy is needed to set up or manage the life of society, nation, State, in all aspects of the lives of many people living in urination; 4) public policy is one tool or device is needed to achieve the goals that have been set by the Government on behalf of the public interest.

The process of public policy, at the very least include: 1) the formulation of a problem; 2) Forecasting; 3) Recommendations; 4) Monitoring; 5) evaluation. Innovative public policy always should be: 1) based upon the public interest; 2) planning, execution, and oversight, as well as his engaging public participation; 3) their definitions are always dynamically moving in accordance with the development aspirations of the public.

The terminology of public policy (public policy) it turns out much at all, depending on the corner where we perceive it. Easton gives a definition of public policy as the authoritative allocation of values for the whole society or as an assignment in the forced values to all the community members 2). Laswell and Kaplan also define public policy as a projected program of goal, value, and practice or program goal achievement, values in the practices. Other public policy sense also revealed by Anderson which States public policy as a purposive course of action followed by an actor on the set of an actors in dealing with a problem or matter of concern or as actions that have the purpose of particular that followed and implemented by a principal or a group of perpetrators in order to solve a problem.

According to the public policy aspects of Dye (1995) in Susy Susilawati (2007) can be defined as everything done Government, why they do, and the results that make a life together performing different (what government do, why they do it, and what difference it makes). Dumn (2003) in Susy Susilawati (2007) suggests that public policy is a complex dependence pattern of collective choices that are mutually dependent, including decisions not to act, made by the body or the Office of the Government.

The stakeholders here are individuals, groups, or institutions having an interest against a policy. This policy can be a stakeholder of the actors involved in the formulation and implementation of policy, the beneficiaries as well as victims harmed by a public policy. There are three groups of key stakeholders stake holders i.e., primary, and secondary stakeholders (Suharto, 2007 in Yuli and his friends, 2012). While the public policy process itself consists of three stages, namely the formulation, implementation, and evaluation (in Yuli and his friends, 2012).

\section{$>$ Public policy}

Public Transparency is a principle that guarantees access or freedom for everyone to obtain information about the Organization of the Government, that is, information about the process of making policy, and the implementation, as well as the results achieved. Assumptions can be formulated, more transparent public policy, which in this case is a GRANT then supervision is performed by the Board will be increased because the society is also involved in overseeing public policies (Yulinda and Lilik in Earn Rudiyanto, 2012).

Implementation of policies is a process implementing the policy decisions made by the individual/group or Government officials as well as private in order to achievement of the objectives outlined in the policy decisions that will affect the final results of a policy. With regard to the success of the implementation of the policy, edward III suggested four factors that affect the implementation of the same policies or whether a policy is successful (1) communication (2) resources (3) Dispositions/Attitudes (4) Structure Bureaucracy.

\section{$>$ The theory of policy}

Formulation policy formulation was the initial policy in public policies. In either the theory of policy formulation, there are at least 13 (thirteen) of the types of policy formulation, namely, institutional theory, theory, theory of process groups, the elite theory, the theory of rational, incremental theory, game theory, public choice theory, theory the system of integrated observations, theory, theory, theory of strategic, democratic and deliberative theories (in Burhanuddin, 2009).

\section{Perspectives of Management Development}

\section{- Understanding management}

Mary Parker Follett Management sense for example, defines management as the art work through other people. This definition means that a Manager is in charge of organizing and directing others to achieve the goals of the organization. Ricky W Griffin defines management as a process of planning, organizing, coordinating, and controlling resources to achieve objectives (goals) effectively and efficiently. Effectively means that the goal can be achieved in accordance with the planning, while efficient means that the task was carried out correctly, well organized, and within the planned timetable.

Mary Parker Follett in Hani Handoko defines management: u.s. art in finishing work through others, as art in the finished work through other people. Described next, in achieving the objectives of the Organization, the Manager uses another person or it can be said the Manager did not do the 
tasks themselves in achieving the objectives of the organization. So, it can be concluded in this case that the function of the Manager is to manage and direct the others to achieve the goals of the organization. James AF Stoner in Supono Boedyo (2011) provides a definition of management is the process of planning, organizing, and directing the surveillance efforts of the members of the Organization and use of resources-the resources of other organizations in order to can achieve the goals of the organization.

Management is a science that studies how to achieve objectives effectively and efficiently using the help through other people (in a broader sense in the form of assistance in the form of the thought, effort and you may also intuition. ( Lamidjan Muntiani and Bambang in 2012). The main element is the management in an organization. The organization can be said to be successful, if already set up its members to run the task each. According to Andrew F Sikula, management is:

Development of Successful regional development planning was not, of course, can not be detached from the mass media in it. Why like that, because the Government, the press, and the public is an aggregation of mutually need each other (Pandia Idawati, 2008). Broadly speaking, it can be identified three patterns of thought and practice development that developed in Indonesia, which each emphasized different approaches, namely the emphasis the political, economic, and moral imperative as a commander.

According to Full-blooded Mardikanto: development is defined as a conscious effort and planned to implement a change - a change that leads to economic growth and improved quality of life or well being of all citizens, especially for long term. This effort was undertaken by the Government which is supported by the participation of the citizens by using technology. Whereas Lion berger and Gwin defines development as a process of problem solving, whether problems faced by agencies in every level of government bureaucracy, among scientists and extension officers, or the problems faced by citizens the community.

The term development could be interpreted differently by each person, the one with the other, or one with other countries. It is important for us to be able to have the same definition in the means of development. Traditionally, the development means the continuous improvement in the Gross Domestic Product (GDP) or gross domestic product (GDP) of a country. For the area, meaning that traditional development focused on GDP of a provincial, city and County (RM Riadi and Caska, 2008). In the great dictionary of Indonesian Language means, the development process, the ways, and the deeds of the building (researcher Mochamad, dkk, 2012).

Kartasasmita in Redatin, dkk (2013) are of the opinion, in order to empower the people, then it should be created a climate that can develop the potential and power of the community. Construction managers have to show partiality in earnest on the populace in order to open the management development opportunities to empower communities through improving the quality of human resources (HR) as a real step in the develop the initiative, participation, NGOs, as well as encourage, motivate, and raised awareness of the potential. Instead, without any partiality in earnest from the management development will make the direction of community empowerment becomes a blur.

\section{$>$ The concept of the Management of Urban}

Development Management can be defined as an attempt to do a management process that is organizing and coordinating the conditions/city system that exists today, namely the factors of production in the city is good in the form of land, labor, capital, and entrepreneurship (enterpreunership) so that the achievable maximum results and efficiency towards the desired city system is based on the ideal destination and dynamic.

Process management is the management of the implementation stages of the program and its calculation technique development. This process involves several stages of activities ranging from stage to stage of goal setting for controlling the implementation of development programs. As for the management process includes the following description: a. Purpose b. Assignment Briefing c. Controlling d. Government Community.

\section{RESEARCH METHODS}

Qualitative research approach through kind of
Phenomenology.

\section{DISCUSSION}

\section{A. Empowerment of traditional market traders}

Collaboration The existence the presence of traditional markets is very important, which awoke the shades is the feel good family fellow traders as well as to the community, when we observe the transaction woke up the market is not that expensive either traditional products vegetable mayor, rice, fish and so on, this is due to the goods being bought more dollars to the basic necessities, the source of raw material mostly provided the seller at the same time also they are farmers, or as the second party in terms of the distribution of goods, the concept of buying and selling in the traditional market has been long underway and already created since hundreds of hundred years ago, the concept of traditional markets in general are still widely embraced the model the exchange of goods with goods or goods with the money, according to the agreement established between them, the traditional market is where the merging of seller and buyer as well as a marked presence of transaction buyer and seller directly, usually with pattern bargaining. The building usually consisted of stalls, los, and essentially open opened by the seller or a person who manages the market. With the changing times the starting forward, any market experienced growth in terms of buildings and services. The market evolved into a 
requirement that must be met in the modernization era, then comes the term traditional markets and modern markets.

Generally traditional markets frequented by middle-class down and most of the traditional market it was owned directly by the local government local government in General have a department dealing with market and manage traditional markets. This service manages the market alone or cooperates with the private sector. It has become a habit for the service of the market to determine annual admissions targets for each market manager, which often increases every year. Failure to meet the target usually has an impact at the turn of the head manager of the market.

Traditional market conditions currently increasingly shrinking due to the growing proliferation of today's modern market such as supermarkets, stores, malls and more. For it is no less traditional markets in order to compete with modern markets the Government must begin to provide and maintain an adequate service infrastructure for the users of the services market, namely the comfort and cleanliness of the market environment.

Considering it has been proven that traditional markets are able to exist and endure since the crisis, both the traditional markets that are in, or capable of in the village still exist even though the storms of economic crisis, so that the existence of traditional markets need to get the attention of the Government to contribute in terms of sustainability of the traditional market.

The activities and the presence of traditional markets is not something that makes the other sectors will be knocked out, it is evident that the bustling traditional market visited the community does not have an impact on the level of the purchaser on the modern market, and the various activities of the society makes these conditions have an impact to the fulfillment of the needs that didn't get bought in the morning can be purchased at the time of the afternoon or evening, and this member benefit both parties either modern or traditional market in trade transactions of the existence of economic crises that have occurred in Indonesia gave a positive impact and impact negative to improve the welfare of society Indonesia. On the one hand, the crisis has brought tremendous impact on poverty levels, but on the other hand, the crisis could also give a blessing in disguise for the efforts an increase in welfare of the whole people of Indonesia in the days to come. This is due to the economic crisis and the trust that has paved the way for the emergence of a total reform in all aspects of the life of the nation of Indonesia.

The economy is an important aspect that can support the advancement of a nation. A great nation is a nation that is able to grow and advance economic sectors either formal or informal sector, to observe the equitable distribution of income for its citizens. Progress in the field of economics was also influenced by technological advances and the changing times that feels fast. When looking the history of human civilization, in the beginning of economic activity in the form of a transaction between the merchant and the buyer of the goods is done in exchange of goods (barter), namely economic activity by conducting a transaction of goods with goods in order to meet the daily needs. Own goods exchange goods began to be abandoned since the advent of the currency used as a measuring instrument of payment of the goods and service also. Economic development is closely associated with the development of the times with the advent of the era of globalization is characterized smeared on the world of business and commerce, city planning, complete with facilities and supporting facilities in order to access make it easy in everyday life. One means of market economy which became a benchmark in the revenue increase of the economy in the region. And when devoted to the area's market district, the only place where economic transactions take place.

The traditional market is a great place to assess the level of community economy in the district, village and community welfare should constitute the highest level of the Government's success in carrying out its duties and functions as a working apparatus for the people. In the construction and development of the traditional market in areas districts, as for the factors into consideration, namely the measurement of population to know the substance of the needs of the local community, so that the construction market in accordance with the needs of the population.

The main purpose of the implementation of the development of traditional markets is creating a welfare society, one of the efforts in achieving this by developing traditional markets began is not feasible because development is the beginning of empowerment means of Government facilities and the community. If the community is satisfied with the more market development actions undertaken local governments then society will provide confidence to the Government, as well as the opposite of empowerment of economic means in particular facilities, traditional market It is one of the pillars in the creation of good governance.

The role of the Central Government as well as much needed areas, in addition to support from all stake holders, the private sector, academia is very important in order to ensure that existence traditional market can still be maintained, this is due to that market's traditional It is the legacy of the past activities of the hereditary and became the arena of hospitality between citizens.

The role of local government is the absolute thing that became a benchmark of the ongoing construction of the traditional market, because good governance paradigm in local Governments had an important role in developing regions. Traditional market in an area is the means by which became a benchmark in enhancing community welfare especially in areas far from the town center of economic development of the people surged. The role of the Government in improving the welfare of society is very important. By basing on the teachings of Islam, the Government has some functions of its 
responsibility towards society, social security, social balance and Government intervention.

The traditional market at a time of economic crisis the crisis does not make the activity traders in traditional markets suffered destruction, so the Government needs to make a concerted effort to keep preserving the existence of the traditional market, the existence of traditional markets have a strong capacity to survive in the macroeconomic situation is uncertain and no such formal economic activity slumped or large-scale economic activity. The participation of traditional market functions as a rescue network and provider of employment for most people. On the other hand the market provides everyday needs in the number, types and prices varied according to the circumstances of erratic financial community at a time of crisis. Some markets provide commodities and services which become part of the identity of a city or region. From the interests of local governments, the market gives revenue continuously and directly to local government coffers. Based on the perspective of the Government strategic development design traditional markets need to be done because this is a mandate from the 1945 constitution article 33 which mentions the national economy based on economic democracy in favor of people. In tune with RPJPN 2005-2025 explaining discover about empowerment of cooperatives and micro, small and medium enterprises (UMKM). In program implementation and regulation for the development of these traditional markets are demanding a major role of local governments, according to law No. 32 Year 2004 about local government that the responsibility first and foremost in the era of autonomy in prospers society is on the shoulders of the local government. One of the functions and objectives of the establishment of a country is to create well-being and prosperity for its people.

\section{B. Raditional Market Strategy}

With a proliferation of hypermarkets or supermarkets currently the existence of traditional market started less interest, this is certainly going to make things worse the economic lower class society, traditional markets will disappear sink over the high wall hypermarkets, for it required strategic measures in order to make traditional markets still exist, such as: traditional market in order for improvements to do be able to compete with modern markets. among other things, is to make the policy of the Government that supports the development of traditional markets, restructure the market to be more clean, fresh, airy and impressed, Then attempted to let the food for sale as fresh as possible because this is the characteristic of the traditional market, another attempt is the promotion should be more vigorous and oriented on showing the identity of the to tradition, the regulation of Market Zones, there is a Government policy which governs the regulation of the market, especially the zone for modern markets, this policy certainly must be operates on the existence or the existence of the traditional market, the establishment of modern markets or hypermarkets or supermarkets need to be restricted or prescribed amount in one region where there is the traditional market, restrictions operating time from hours $10.00-22.00$
GMT this as a limitation of the consumer and as protection on the modern market so that the continuity of traditional market persists, the existence of government intervention to modify or improve regulatory disadvantage traditional markets, the Government gives special attention to traditional markets.

\section{CONCLUSION}

Traditional market presence is the Foundation in the strengthening of the economic community as a macro, this is due to the wheel of the economy in the country of Indonesia as a developing country is more based on the strengthening of the economic populist in the wrap of the asa please each other help, economic activities in the traditional market imposes upon the implementation of the economic activities that have an impact on development in many other fields, for that Government needs to build the economy of the traditional market traders by involving various aspects and all stake holder, private as well as academicians to together while maintaining traditional markets in order to keep it running in the middle of the progress of the city and in the middle of the large number of modern market today.

\section{REFERENCES}

[1]. ASEP Sudrajat (2013), "Unemployment and poverty in Indonesia", http://jajukal.blogspot.com/.

[2]. Alwi (2006). "The concept of Good Governance in the concept of autonomous region", the journal of Administrative and Policy Analysis, Volume 3, number 1, January - April 2006.

[3]. Burhanuddin (2009), "public service policy on Education in West Sumbawa Regency () of the province of Nusa Tenggara Barat" Mataram University PEDAGOGY, 2009.

[4]. Bambang and Muntiani (2012). "Information Systems Management Practices field work on the course Webbased information system", Chrysanthemum FTI UNSA 2012 Volume 1 ISSN: 2302-1136.

[5]. Dede Mariana (2010), "Regional Autonomy and innovation policy", governance, vol. 1, no. 1, January 2010.

[6]. Earn Rudiyanto (2012), "the influence of the knowledge of the Board's financial Oversight Areas Against Tentanganggaran (GRANT), with community participation and transparency of public policy as a Moderating Variable (Empirical Studies on DPRD Karanganyar Regency)", Journal of the Faculty of Economics Publications Muhammadiyah University of Surakarta 2012.

[7]. Gary w. Evans (2004), "The Environment of Childhood Poverty", American Psychologist, vol. 59, no. 2, 77 92.

[8]. Hadi Sasana (2011), "an analysis of the Determinants of shopping areas in the district/city of West Java province in an Era of Fiscal Decentralization And Autonomy", Journal of business and Economics (JBE), March 2011, vol. 18, no. 1, ISSN: 1412-3126. 
[9]. Idawati Pandia (2008), "public opinion Regarding the role of local print Media in the development of Agriculture and horticulture (survey in the village of Siroga and the village of Ndokum Sub-district Surbakti Karo district)", BBPPKI, 2008.

[10]. Julisar An-Naf (2005), "sustainable development and its relevance to Indonesia", Journal of Madani: Edition II, November 2005.

[11]. J. Edward Taylor and Thomas Reardon (1996), "Agroclimatic Shock, Income Inequality, and Poverty: Evidence from Burkina Faso," World Development, vol. 24 , no. 5.

[12]. Researcher Mochamad, dkk (2012). "The construction of the Media Learning computer engineering Class Chain X Odd Semester in high school Vocational Midshipman Starch-based Nation Interactive Multimedia", English Journal on Computer Science Speed (IJCSS) 13 FTI UNSA Vol 9 No 3 - December 2012ejournal.unsa.ac.id.

[13]. Martin Ravallion (1995). "Growth and poverty: Evidence for developing countries in the 1980s", Economics Letters 48 (1995) 411-417.

[14]. Martin Ravallion (1997), "Can the developing highinequality countries escape absolute poverty?", Economics Letters, vol. 56 (1997): 51-57.

[15]. Paul Mosley and David Hulme (2009) "Microenterprise Finance. Is there a conflict between growth and poverty alleviation? ", ISBN 0-203-88276-8 Master e-book ISBN.

[16]. Retno Purbayudan (2005). "Analysis of Area's original Revenue (PAD) and the factors that affected him in the effort of implementing Regional Autonomy In Kediri Regency", Journal of development Dynamics, vol. 2 No. 1/2005 lull: $9-18$.

[17]. RM Riadi and Caska (2008), "the growth of Interregional economic development and inequality in Riau Province", Journal of industrial and urban Volume XII Number 21, March 2008. Redatin, dkk (2012), "the impact of organizing the race Village towards community empowerment in development in West Kalimantan (study in the village of Pal IX Subdistrict River Snapper, Regency Kubu Raya)", journal Thesis PMIS-UNTAN-PSS-2013.

[18]. Rofiuddin Mohammad (2012), "analysis of financial performance Area on the island of Madura, East Java province in the autonomous region of the year 20052009", publication of the journal of the Faculty of Economics University of Muhammadiyah Surakarta 2012.

[19]. Susy, (2007). "Public policy analysis of the field of Work safety and health in the town of Tasikmalaya," thesis, Diponegoro University 2007.

[20]. Yuli dkk (2012), "public policy that is Participatory and communicative", Journal of public policy, Volume 3, number 2, October 2012, pp. 59-141. 